\title{
Hypoxia-dependent Protein Expression: Erythropoietin
}

\author{
MICHELE SAMAJA
}

\begin{abstract}
Michele Samaja. Hypoxia-dependent protein expression: erythropoietin. High Alt Med Biol 2:155-163, 2001.-Normal cell homeostasis relies on the ordered flow of nutrients and substrates through metabolic pathways. Any perturbation of this flow eventually leads to dysfunction, impairment of defense mechanisms, loss of viability and death. High altitude and pathological hypoxia represent a serious and frequent cause for the loss of cell viability. Although organisms customarily respond by triggering adaptive or maladaptive mechanisms, all forms of life eventually succumb to hypoxia if it is severe enough, irrespectively of the primary cause. This paper reviews one of the mechanisms by which organisms respond to hypoxia: erythropoiesis. Although such response is not always beneficial, the discovery of the biochemical mechanisms underlying erythropoiesis has triggered an active field of research that is actually applying lessons learned in the mountains to a more clinical environment.
\end{abstract}

Key Words: erythropoietin, $\mathrm{O}_{2}$-dependent gene expression, tumor growth, ischemia

\section{INTRODUCTION}

$\mathbf{E}^{\mathrm{R}}$ RYTHROPOIETIN (EPO) IS A KEY blood protein that mediates some of the responses to altitude hypoxia. Originally thought to be only an erythropoietic factor, other functions of EPO are now being discovered. More important, the studies on EPO have triggered research aimed at understanding the body response to hypoxia and other situations such as tumors, ischemia and fetal life (Fig. 1). This paper briefly reviews how EPO has become a paradigm to understand human adaptation to hypoxia.

\section{SUBSTRATE- AND ENZYME- LIMITED REACTIONS}

Enzymes catalyze all the body reactions. Enzymatic reactions are controlled either by the concentration of one or more substrates (firstor superior-order kinetics), or by enzyme activity (zero-order kinetics). Before the explosive growth of cellular and molecular biology, hypoxia studies were under the influence of the idea that responses to hypoxia are governed by rules linked to the cellular economy of substrates supply and demand (Hofmeyr and Cornish-Bowden, 2000). Now, enzyme activity is perceived to be the limiting factor. The two views are not necessarily in contrast, but whereas substrate-limited reactions generally concern short-term adaptation (seconds to minutes), enzyme-limited reactions concern longterm (hours to years) or generational adaptation. Indeed, hypoxia tolerance triggered by substrates adjustments cannot be extended by more than a factor of 3 or 4 (Hochachka, 1986), and would induce the problem of self-pollution by production of undesirable end-products.

Dipartimento di Medicina, Chirurgia e Odontoiatria, Università di Milano, Milan, Italy 


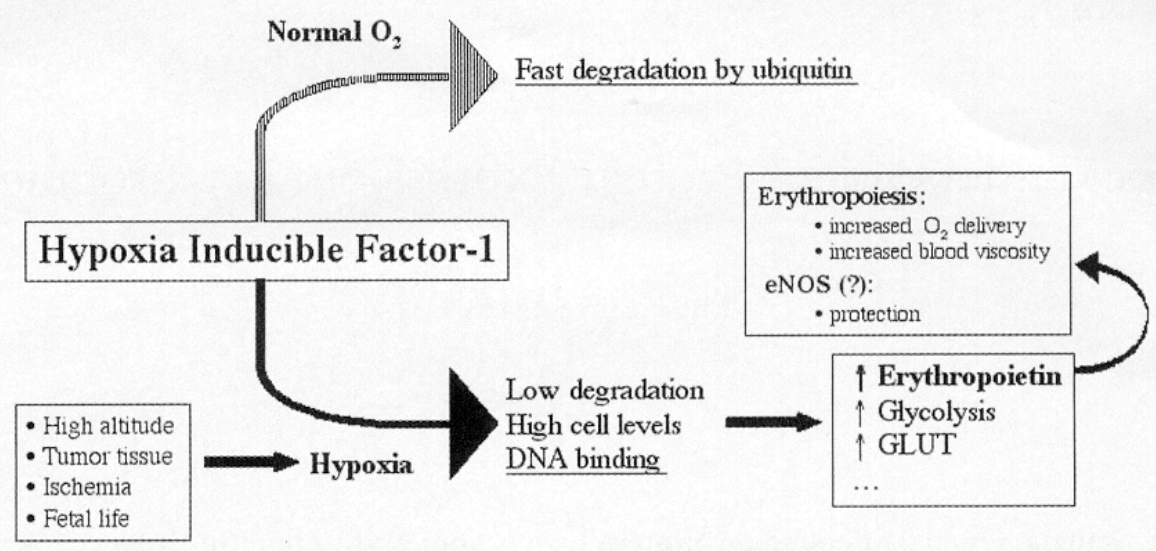

FIG. 1. Schematic model that describes the role of the Hypoxia Inducible Factor in the response to hypoxia.

\section{ERYTHROPOIETIN}

Since Viault's original observations in 1890, despite noticeable racial (Winslow et al., 1989) and gender (Moore et al., 1994) differences, erythropoiesis was found invariably increased in all altitude studies. Although suspected for many years, the hormonal regulation of erythropoiesis was proven only in 1953, when an erythropoietic factor, EPO, was found in the blood of anemic rabbits (Erslev, 1953). EPO is a $30.4 \mathrm{kDa}$ glycoprotein produced by fetal liver and adult kidney in response to hypoxia. For many years, the standard method to measure EPO was an expensive and tedious mouse bioassay (Adamson and Finch, 1975). Later, sensitive and specific RIA (Knaupp et al., 1992) and ELISA (Noe et al., 1992) were developed. The misuse of recombinant human EPO (rHuEPO) to boost physical performance has triggered research aimed at detecting such practice, but those methods cannot differentiate endogenous from exogenous EPO. Many techniques were proposed for the new purpose (Lippi and Guidi, 2000), including ELISA optimized to detect murine, but not other types of EPO (Noe et al., 1999). Attempts to correlate EPO with other blood indexes were also controversial (Magnani et al., 1999; Bonfichi et al., 2000). Only in 2000, an alternative ELISA could differentiate endogenous EPO and rHuEPO in the urines (Lasne and de Ceaurriz, 2000).

\section{HYPOXIA AND EPO}

Hypoxia is a primary EPO stimulator. In early field studies, conducted at altitudes near $4500 \mathrm{~m}$, serum EPO increased within $24 \mathrm{~h}$ after ascent (Milledge and Cotes, 1985), reached a peak $48 \mathrm{~h}$ after, then remained elevated for at least 9 days (Abbrecht and Littel, 1972), before slowly decreasing to sea-level normal. Urinary EPO, after a latent $6 \mathrm{~h}$ period, peaked in $24 \mathrm{~h}$, and then fell to a plateau about twice as sealevel in $48 \mathrm{~h}$ (Faura, 1969). There was no striking correlation between individual EPO variation and erythropoietic responses (Milledge and Cotes, 1985). In these field studies, however, dietary and training variables may have confounded data. In more controlled studies, carried out in animals and/or hypobaric chambers, the minimum exposure to hypoxia needed to elicit EPO production was not high: sojourning at $3000 \mathrm{~m}$ or $4000 \mathrm{~m}$ for $5.5 \mathrm{~h}$ increased EPO by $80 \%$ or $300 \%$, respectively (Eckardt et al., 1989).

Not only altitude hypoxia, but also all the conditions associated with polycythemia, such as lung disease (Weil et al., 1968), congenital heart disease (Tyndall et al., 1987), abnormal hemoglobins (Adamson et al., 1969) and obstructive sleep apnea (Cahan et al., 1989), tend to increase EPO. EPO is also increased by situations such as blood acid/base imbalances (Eckardt et al., 1990), physical exercise (Schmidt 
et al., 1993), training (Berglund, 1992) and circadian rhythms (Klausen et al., 1993), with hyperoxia constantly acting as an antagonist.

Repeated intermittent exposure to hypoxia is being used with increasing frequency. Not only is it part of pre-acclimatization strategy before high altitude expeditions, but also it may replace the costly rHuEPO administration in patients with cancer, end-stage renal disease, hemodialysis, anemia, as well as for overcoming the effects of anemia after autologous preoperative blood donation. In addition, intermittent hypoxia is associated with clinical conditions including sleep apneas, lung diseases and asthma. Exposing humans to hypoxia for $5 \mathrm{~min}$ or $60 \mathrm{~min}$ did not induce EPO, but $120 \mathrm{~min}$ or intermittent $240 \mathrm{~min}$ exposures provided a sufficient stimulus to raise EPO (Knaupp et al., 1992). Short (90 min) daily exposures to hypoxia at simulated altitude of $5000 \mathrm{~m}$ for 3 weeks elicited EPO production with accompanying erythropoietic response (Rodriguez et al., 2000).

\section{THE ERYTHROPOIETIC FUNCTION OF EPO}

Circulating EPO binds to EPO receptors on the erythroid progenitor in the bone marrow, enabling it to proliferate and differentiate faster into adult red blood cells by repressing apoptosis (Silva et al., 1996). As the main function of red cells is to transport $\mathrm{O}_{2}$, higher red cell mass should lead to higher blood $\mathrm{O}_{2}$ capacity. Practically, this advantage is partially blunted by increased blood viscosity, which leads to poor performance, arterial hypertension and retinal hemorrhage (Winslow and Monge, 1987). The role of polycythemia is however difficult to focus because increased red cell mass also increases total blood volume (plasma volume does not decrease in proportion), with concomitant increased cardiac output, which complicates interpretation of data obtained in the absence of blood volume measurements.

However, stimulated erythropoiesis tends to "rejuvenate" the circulating red cell pool. As a potent modulator of the hemoglobin function, the red cell metabolite 2,3-diphosphoglycerate, declines in proportion to the time spent in the circulation, a "younger" red cell population leads to improved $\mathrm{O}_{2}$ delivery to tissues independently of the increased red cell mass (Samaja et al., 1993). As a consequence, peripheral oxygenation is improved. The observation that rHuEPO administration reduced lactate release during exercise and lowered the use of glycogen by increasing that of free fatty acids (Manitius et al., 1995) might be justified by improved tissue oxygenation, but it remains unclear if EPO directly influences the expression of some enzymes of the lipid-carbohydrate metabolism.

\section{NON-ERYTHROPOIETIC EFFECTS OF EPO}

EPO receptors are present not only in the bone marrow erythroid progenitor, but also in other tissues; therefore, EPO has other lessknown effects unrelated to erythropoiesis. First, when the red cell mass increase was triggered by EPO, the corresponding increase in blood viscosity was less than expected. Transgenic mice overexpressing EPO developed polyglobulia, but not hypertension nor thromboembolism (Ruschitzka et al., 2000). This study also reported increased endothelial NOsynthase in transgenic mice, although the mechanism was not elucidated. In principle, the EPO-induced NO release confers protection because it counteracts, at least partially, the effect of increased blood viscosity on peripheral vascular resistance. This important result is however to be taken with caution, because another report clearly shows that, in endothelial cultured cells, by depressing endothelial NOsynthase, EPO down-regulates NO production (Wang and Vaziri, 1999).

Second, EPO is expressed in the brain (Tan et al., 1992), specifically by astrocytes (Marti et al., 1996), while EPO receptors are placed on the neuronal cells (Digicaylioglu et al., 1995). Direct intracerebroventricular injection of $\mathrm{rHuEPO}$ in advance of hypoxia, ischemia or trauma offered protection to neuronal tissue (Brines et al., 2000). This finding, which indicates paracrine and/or autocrine functions of EPO in the nervous system, and the postulated impermeability to proteins of the blood-brain barrier, support a local protective function of EPO (Sakanaka et al., 
2000). The level of rHuEPO needed to afford protection is much higher than the doses required to elicit erythropoiesis, but high doses are apparently without adverse effects (Brines et al., 2000). Two mechanisms were hypothesized (Marti et al., 2000): (1) EPO protects directly neurons by repressing apoptosis, in analogy to the antiapoptotic action in erythroid precursor cells; (2) EPO indirectly enhances angiogenesis through stimulation of VEGF (see below). However, the observation that EPO can cross the blood-brain barrier by endocytosis followed by translocation (Brines et al., 2000) will probably somewhat change our knowledge on this phenomenon.

Last but not least, EPO has become an ideal paradigm for studying $\mathrm{O}_{2}$-dependent gene expression (Bunn et al., 1998). Human hepatoma cell lines, which produce EPO in a physiologically-regulated manner, i.e., induced by hypoxia, provided an excellent in vitro model to study EPO responses to hypoxia (Ratcliffe et al., 1997). In general, cells reduced their total mRNA synthesis by $50-70 \%$ under hypoxia, but an increasing number of genes was stimulated by hypoxia (Fandrey, 1995). Of the factors proposed as regulators of hypoxia-induced gene expression, $\mathrm{NF}-\kappa \mathrm{B}, \mathrm{AP}-1$ and the tumor suppressor $\mathrm{p} 53$ are induced at $\mathrm{PO}_{2}<1 \mathrm{mmHg}$, therefore they are thought to be implicated in ischemic, rather than hypoxic syndromes. However, expression of the hypoxia-inducible factor- $1 \alpha(\mathrm{HIF}-1 \alpha)$ varied exponentially over a wide range of $\mathrm{PO}_{2}$ (Jiang et al., 1996), which led to the idea that this factor is the main transducer of the hypoxic signal into the cell.

\section{HYPOXIA-INDUCIBLE FACTOR- $1 \alpha$}

The structure of HIF- $1 \alpha$ is now well characterized (Semenza, 1998) and the localization of its gene on human chromosome 14 is established (Semenza et al., 1996b). Technically, HIF$1 \alpha$ is a member of the helix-loop-helix PAS family, which belongs to the factors that regulate DNA transcription into mRNA by binding to DNA in the correspondence of specific sequences, or motifs, that are situated upstream of many hypoxia-induced genes (Wang et al., 1995). When HIF- $1 \alpha$ recognizes one of these se- quences on the DNA strand, it binds to DNA, thereby inhibiting further transcription of that DNA section. When HIF- $1 \alpha$ is destabilized, this function is blunted and DNA transcription may proceed. Structurally, HIF-1 is a dimer composed of a $\beta$ subunit, which is relatively stable and acts as a constitutive factor (Wood et al., 1996), and the $\alpha$ subunit, which is degraded rapidly and is therefore the limiting factor in the reaction chain (Huang et al., 1998). During hypoxia, the $\alpha$ subunit becomes stabilized, leading to stabilization of the dimer, its binding to DNA, and inhibition of DNA translation into mRNA.

The increase of HIF- $1 \alpha$ during hypoxia was defined "dramatic" (Gassmann and Wenger, 1997). Therefore, it is not likely that hypoxia affects HIF- $1 \alpha$ at the genetic level, but hypoxia might affect the post-translational up-regulation of HIF, probably by increasing the protein stability (Huang et al., 1998). Indeed, in cells exposed to $21 \% \mathrm{O}_{2}, \mathrm{HIF}-1 \alpha$ is rather unstable (half-time $<5 \mathrm{~min}$ ) owing to its susceptibility to degradation by ubiquitin (Sutter et al., 2000; Huang et al., 1998). Low $\mathrm{O}_{2}$ tension inhibits degradation (half-time several hours), thereby allowing intracellular accumulation of HIF- $1 \alpha$. There are at least four mechanisms responsible for the post-translational stabilization of HIF$1 \alpha$ during hypoxia (Chandel and Schumacker, 2000):

- Allosteric shifts in a heme-protein (Goldberg et al., 1988).

- Ion currents modulation and electrophysiological alterations by $\mathrm{O}_{2}$-sensing ion channels, as in neurons, where ATP-sensitive $\mathrm{K}^{+}$ channels are activated by hypoxia to increase survival (Yun et al., 1997) and prevent $\mathrm{Ca}^{++}$ overloads (Bickler and Buck, 1998).

- Oxido-reductive changes affecting NADPH oxidase, a universal $\mathrm{O}_{2}$ sensor (Jones et al., 2000), as in pulmonary vasoconstriction (Voelkel and Tuder, 2000).

- Incomplete reduction of $\mathrm{O}_{2}$ to water in mitochondria with release of minute amounts of $\mathrm{H}_{2} \mathrm{O}_{2}$, well below those that exerts oxidative stress. Strong experimental evidence supports the view that low $\mathrm{H}_{2} \mathrm{O}_{2}$ production during hypoxia (Kietzmann et al., 2000) influences EPO production in hepatoma cells 
(Fandrey et al., 1997). Thus, $\mathrm{H}_{2} \mathrm{O}_{2}$ is a candidate intracellular messenger between the $\mathrm{O}_{2}$ sensor and the transcriptional machinery controlling the EPO gene (Chandel et al., 2000).

The modulation of HIF- $1 \alpha$ does not influence only EPO, but also has important downstream effects on a number of other genes (Table 1).

\section{HYPOXIA AND $\mathrm{O}_{2}$-DEPENDENT GENE EXPRESSION: A LINK BETWEEN HIGH ALTITUDE, TUMOR GROWTH, ISCHEMIA AND BEYOND?}

Clarification of the basic mechanisms underlying $\mathrm{O}_{2}$-dependent gene expression has trig- gered research into the pathological effects of hypoxia, with the result that biomedical fields that until recently had very little to do with high-altitude studies may now exchange important lessons to and from mountain medicine.

Solid tumors contain hypoxic environments (Helmlinger et al., 1997). It is therefore tempting to speculate that the mechanisms underlying hypoxia adaptation are also involved in tumor growth. A key finding in support to this hypothesis came from the observation that tissue hypoxia increased the expression of several growth factors, including the vascular endothelial growth factor (VEGF) (Forsythe et al., 1996). The implication of VEGF in tumors is now well recognized (Neufeld et al., 1999). VEGF, which is also a cause of HACE (Sever-

Table 1. A Few Downstream Consequences of the Activation of Hypoxia-Inducible Factor $1 \alpha$

\begin{tabular}{|c|c|c|}
\hline Reference & Target & Notes \\
\hline $\begin{array}{l}\text { (Forsythe et al., } \\
\text { 1996) }\end{array}$ & $\begin{array}{l}\text { Vascular endothelium growth } \\
\text { factor (VEGF) }\end{array}$ & $\begin{array}{l}\text { The VEGF enhancer contains a consensus } \\
\text { sequence that closely resembles the HIF- } 1 \alpha \\
\text { binding sequence in the EPO enhancer (Liu } \\
\text { et al., 1995). }\end{array}$ \\
\hline $\begin{array}{l}\text { (Li et al., 1996; } \\
\text { Semenza et al., } \\
\text { 1996a; Firth et al., } \\
\text { 1995) }\end{array}$ & Glycolytic enzymes & The aerobic-to-anaerobic shift is favored. \\
\hline $\begin{array}{l}\text { (Hellkamp et al., } \\
\text { 1991) }\end{array}$ & Gluconeogenesis & Gluconeogenesis is inhibited. \\
\hline (Ebert et al., 1995) & Glucose transporters (GLUT) & $\begin{array}{l}\text { Elevated glucose preference in heart is a true } \\
\text { metabolic adaptation in humans adapted over } \\
\text { generations to chronic hypoxia (Holden et } \\
\text { al., 1995). }\end{array}$ \\
\hline $\begin{array}{l}\text { (Motterlini et al., } \\
\text { 2000; Bergeron et } \\
\text { al., 1997) }\end{array}$ & Heme oxygenase, or HSP32 & $\begin{array}{l}\text { Bilirubin, a product of the reaction, confers } \\
\text { protection. }\end{array}$ \\
\hline $\begin{array}{l}\text { (Czyzyk-Krzeska et } \\
\text { al., 1992) }\end{array}$ & Tyrosine hydroxylase & The synthesis of DOPA is increased. \\
\hline (Melillo et al., 1995) & Nitric oxide synthase & $\begin{array}{l}\text { Inducible NOS increases, but endothelial } \\
\text { NOS decreases }\end{array}$ \\
\hline $\begin{array}{l}\text { (Michiels et al., } \\
2000)\end{array}$ & $\begin{array}{l}\text { Inflammation and cytokine } \\
\text { release }\end{array}$ & $\begin{array}{l}\text { HIF- } 1 \alpha \text { activates endothelial cells to release } \\
\text { inflammatory mediators and growth factors } \\
\text { (promoting neutrophils adherence to tissue), } \\
\text { and increase expression of genes encoding } \\
\text { cytokines, platelet- and vascular-derived } \\
\text { growth factors. }\end{array}$ \\
\hline (Kacimi et al., 1995) & G protein & Desensitization to catecholamines. \\
\hline
\end{tabular}


inghaus, 1995), mediates vascularization and survival in the growing tumor (Gassmann and Wenger, 1997). Actually, HIF-1 $\alpha$ was activated in solid tumors, thereby controlling tumor vascularization and growth (Carmeliet et al., 1998). In addition, tumors lacking HIF- $1 \alpha$ or HIF- $1 \beta$ failed to develop vascularization (Carmeliet et al., 1998). Of interest, the mechanisms that originate VEGF share multiple common features with those that originate EPO. In a specific case, the von Hippel-Lindau tumor, a direct link was identified between the responsible protein, a tumor gene suppressor, and the cell levels of HIF-1 $\alpha$ (Kamura et al., 2000).

The link between hypoxia and ischemia originates from the observation that ischemic tissue is also hypoxic. Although the two stresses have long been considered distinct, in a perspective series dedicated to the tissue responses to ischemia, Semenza proposed that HIF- $1 \alpha$ makes part of the adaptive responses to survive ischemia (Semenza, 2000). Indeed, heat-shock proteins, some of which are inducible by hypoxia, as HSP70 and heme-oxygenase 1 (Kacimi et al., 2000), might induce a transient protection against the damage caused by ischemia-reperfusion. The $72-\mathrm{kD}$ stress protein also afforded anti-ischemic protection (Marber et al., 1994). As a consequence, HIF-1 $\alpha$ and the hypoxia response element on the DNA strand are now being tested for angiogenic therapy of tissue ischemia (Carmeliet, 2000).

Being extremely hypoxic, Barcroft defined fetal life as "Mt. Everest in utero" (Barcroft et al., 1923). Mammal placenta, which develops in a relatively hypoxic environment, with placental $\mathrm{PO}_{2}$ increasing around 10-12 weeks of gestation in humans, must exchange proper signals in order to induce trophoblast differentiation at the right time. HIF- $1 \alpha$ was expressed at high levels before then, and began to deactivate with raising $\mathrm{PO}_{2}$, thereby inducing trophoblast differentiation through inhibition of TGF $\beta 3$ expression (Caniggia et al., 2000). In pregnancies complicated by early-onset preeclampsia, TGF $\beta 3$ remained elevated, as a part of failure to respond to hypoxia-induced apoptosis in trophoblasts (Levy et al., 2000). EPO is also an important factor for estrogen-dependent cyclical angiogenesis in the uterus (Yasuda et al., 1998).

\section{CONCLUSION}

It is striking to note how the study on EPO has evolved during the last century. EPO started as a mysterious erythropoietic hormone, difficult to assay, but found only in the mountains. Then, it evolved as a drug to treat anemia and boost physical performance. Finally, it turned to be a workbench to understand $\mathrm{O}_{2}$-dependent gene expression, with important reflects on oncology, embryology, and cardiac-pulmonary medicine.

\section{REFERENCES}

Abbrecht P.H. and Littel J.K. (1972). Plasma erythropietin in men and mice during acclimatization to different altitudes. J. Appl. Physiol. 32:54-58.

Adamson J.W., Parer J., and Stamatoyannapoulos G. (1969). Erythrocytosis associated with hemoglobin Rainier. J. Clin. Invest. 48:1376-1386.

Adamson, J.W. and C.A. Finch (1975). Hemoglobin function, oxygen affinity, and erythropoietin. In: Hemoglobin and the Erythron. edited by Adamson, J.W. and C.A. Finch. pp. 351-369.

Barcroft J., Binger C.A., Bock A.V., Doggart J.H., Forbes H.S., Harrop G., Meakins J.C., and Redfield A.C. (1923). Observations upon the effect of high altitude on the physiological processes of human body, carried out in the Peruvian Andes, chiefly at Cerro de Pasco. Philos. Trans. Roy. Soc. Lond. Biol. Sci. 211:351-454.

Bergeron M., Ferriero D.M., Vreman H.J., Stevenson D.K., and Sharp F.R. (1997). Hypoxia-ischemia, but not hypoxia alone, induces the expression of heme oxygenase1 (HSP32) in newborn rat brain. J. Cereb. Blood Flow Metab. 17:647-658.

Berglund B. (1992). High-altitude training. Aspects of hematological adaptation. Sports Med. 14:289-303.

Bickler P.E. and Buck L.T. (1998). Adaptations of vertebrate neurons to hypoxia and anoxia: maintaining critical $\mathrm{Ca}^{2+}$ concentrations. J. Exp. Biol. 201:1141-1152.

Bonfichi M., Balduini A., Arcaini L., Lorenzi A., Marseglia C., Malcovati L., Bernardi L., Passino C., Spadacini G., Feil P., Keyl C., Schneider A., Boiardi A., Bandinelli G., Greene R.E., and Bernasconi C. (2000). Hematological modifications after acute exposure to high altitude: possible implications for detection of recombinant erythropoietin misuse. Br. J. Haematol. 109:895-896.

Brines M.L., Ghezzi P., Keenan S., Agnello D., de Lanerolle N.C., Cerami C., Itri L.M., and Cerami A. (2000). Erythropoietin crosses the blood-brain barrier to protect against experimental brain injury. Proc. Natl. Acad. Sci. USA 97:10526-10531.

Bunn H.F., Gu J., Huang L.E., Park J.W., and Zhu H. (1998). Erythropoietin: a model system for studying oxygendependent gene regulation. J Exp Biol 201:1197-1201. 
Cahan C., Decker M., Rabinowitz G., Washington L., Arnold J., and Strohl K.M. (1989). Hormonal and biochemical markers associated with sleep apnea. Am. Rev. Resp. Dis. 139:A81(Abstract).

Caniggia I., Mostachfi H., Winter J., Gassmann M., Lye S.J., Kuliszewski M., and Post M. (2000). Hypoxia-inducible factor 1 mediates the biological effects of oxygen on human trophoblast differentiation through TGF_3. J. Clin. Invest. 105:577-587.

Carmeliet P., Dor Y., Herbert J.M., Fukumura D., Brusselmans K., Dewerchin M., Neeman M., Bono F., Abramovitch R., Maxwell P., Koch C.J., Ratcliffe P., Moons L., Jains R.K., Collen D., and Keshett E. (1998). Role of HIF- $1 \alpha$ in hypoxia-mediated apoptosis, cell proliferation and tumor angiogenesis. Nature 394:485-490.

Carmeliet P. (2000). Mechanisms of angiogenesis and arteriogenesis. Nat. Med. 6:389-395.

Chandel N.S., McClintock D.S., Feliciano C.E., Wood T.M., Melendez J.A., Rodriguez A.M., and Schumacker P.T. (2000). Reative oxygen species generated at mitochondria complex III stabilize HIF-1-alpha during hypoxia: a mechanism of oxygen sensing. J. Biol. Chem. (In Press).

Chandel N.S. and Schumacker P.T. (2000). Cellular oxygen sensing by mitochondria: old questions, new insight. J. Appl. Physiol. 88:1880-1889.

Czyzyk-Krzeska M., Bayliss D.A., Lawson E.E., and Millhorn D.E. (1992). Regulation of tyrosine hydroxylase gene expression in the rat carotid body by hypoxia. J. Neurochem. 58:1538-1546.

Digicaylioglu M., Bichet S., Marti H.H., Wenger R.H., Rivas L.A., Bauer C., and Gassmann M. (1995). Localization of specific erythropoietin binding sites in defined areas of the mouse brain. Proc. Natl. Acad. Sci. USA 92:3717-3720.

Ebert B.L., Gleadle J.M., O’Rourke J.F., Bartlett S.M., Poulton J., and Ratcliffe P.J. (1995). Isoenzyme specific regulation of genes involved in energy metabolism by hypoxia, cobalt and desferrioxamine: similarities with the regulation of erythropoietin. Biochem. J. 313:809-814.

Eckardt K.U., Boutellier U., Kurtz A., Schopen M., Koller E.A., and Bauer C. (1989). Rate of erythropoietin formation in humans in response to acute hypobaric hypoxia. J. Appl. Physiol. 66:1785-1788.

Eckardt K.U., Kurtz A., and Bauer C. (1990). Triggering of erythropoietin production by hypoxia is inhibited by respiratory and metabolic acidosis. Am. J. Physiol. 258:R678-R683.

Erslev A.J. (1953). Humoral regulation of red cell production. Blood 8:349-357.

Fandrey J. (1995). Hypoxia-inducible gene expression. Respir. Physiol. 101:1-10.

Fandrey J., Frede S., Ehleben W., Porwol T., Acker H., and Jelkmann W. (1997). Cobalt chloride and desferrioxamine antagonize the inhibition of erythropoietin production by reactive oxygen species. Kidney Int. 51:492-496.

Faura J. (1969). Effect of altitude on erythropoiesis. Blood 33:668-676.

Firth J.D., Ebert B.L., and Ratcliffe P.J. (1995). Hypoxic regulation of lactate dehydrogenase A. Interaction be- tween hypoxia-inducible factor 1 and cAMP response elements. J. Biol. Chem. 270:21021-21027.

Forsythe J.A., Jiang B.H., Iyer N.V., Agani F., Leung S.W., Koos R.D., and Semenza G.L. (1996). Activation of vascular endothelial growth factor gene transcription by hypoxia-inducible factor 1. Mol. Cell. Biol. 16:4604-4613.

Gassmann M. and Wenger R.H. (1997). HIF-1, a mediator of the molecular response to hypoxia. News Physiol. Sci. 12:214-218.

Goldberg M.A., Dunning S.P., and Bunn H.F. (1988). Regulation of the erythropietin gene: evidence that the oxygen sensor is a heme protein. Science 242:1412-1415.

Hellkamp J., Christ B., Bastian H., and Jungermann K. (1991). Modulation by oxygen of the glucagon-dependent activation of phosphoenolpyruvate carboxykinase gene in rat hepatocyte cultures. Eur. J. Biochem. 198: 635-639.

Helmlinger G., Yuan F., Dellian M., and Jain R.K. (1997). Interstitial $\mathrm{pH}$ and $\mathrm{PO} 2$ gradients in solid tumors in vivo: high resolution measurements reveal a lack of correlation. Nat. Med. 3:177-182.

Hochachka P.W. (1986). Defense strategies against hypoxia and hypothermia. Science 231:234-241.

Hofmeyr J.H.S. and Cornish-Bowden A. (2000). Regulating the cellular economy of supply and demand. FEBS 476:47-51.

Holden J.E., Stone C.K., Clark C.M., Brown W.D., Nickles R.J., Stanley C., and Hochachka P.W. (1995). Enhanced cardiac metabolism of plasma glucose in highaltitude natives: adaptation against chronic hypoxia. J. Appl. Physiol. 79:222-228.

Huang L.E., Gu J., Schau M., and Bunn H.F. (1998). Regulation of hypoxia-inducible factor 1 alpha is mediated by an oxygen-dependent degradation domain via the ubiquitine-proteasome pathway. Proc. Natl. Acad. Sci. USA 95:7987-7992

Jiang B.H., Semenza G.L., Bauer C., and Marti H.H. (1996). Hypoxia-inducible factor 1 levels vary exponentially over a physiologically relevant range of $\mathrm{O} 2$ tension. Am. J. Physiol. 271:C1172-C1180.

Jones R.D., Hancock J.T., and Morice A.H. (2000). NADPH oxidase: a universal oxygen sensor? Free Rad. Biol. Med. 29:416-424

Kacimi R., Moalic J.M., Aldashev A., Vatner D.E., Richalet J.P., and Crozatier B. (1995). Differential regulation of $G$ protein expression in rat hearts exposed to chronic hypoxia. Am. J. Physiol. 269:H1865-H1873.

Kacimi R., Chentoufi J., Honbo N., Long C.S., and Karliner J.S. (2000). Hypoxia differentially regulates stress proteins in cultured cardiomyocytes: role of the p38 stress-activated kinase signaling cascade, and relation to cytoprotection. Cardiovasc. Res. 46:139-150.

Kamura T., Sato S., Iwai K., Czyzyk-Krzeska M., Conaway R.C., and Conaway J.W. (2000). Activation of HIF1alpha ubiquination by a reconstituted von Hippel-Lindau tumor suppressor complex. Proc. Natl. Acad. Sci. USA 97:10430-10435.

Kietzmann T., Fandrey J., and Acker H. (2000). Oxygen radicals as messengers in oxygen-dependent gene expression. News Physiol. Sci. 15:202-208. 
Klausen T., Dela F., Hippe E., and Galbo H. (1993). Diurnal variations of serum erythropoietin in trained and untrained subjects. Eur. J. Appl. Physiol. 67:545-548.

Knaupp W., Khilnani S., Sherwood J., Scharf S., and Steinberg H. (1992). Erythropoietin response to acute normobaric hypoxia in humans. J. Appl. Physiol. 73: 837-840.

Lasne F. and de Ceaurriz J. (2000). Recombinant erythropoietin in urine. Nature 405:635.

Levy R., Smith S.D., Chandler K., Sadovsky Y., and Nelson D.M. (2000). Apoptosis in human cultured trophoblasts is enhanced by hypoxia and diminished by epidermal growth factor. Am. J. Physiol. 278: C982-C988.

Li H., Ko H.P., and Whitlock J.P. (1996). Induction of phosphoglycerate kinase 1 gene expression by hypoxia. Roles of ARNT and HIF-1alpha. J. Biol. Chem. 271 21262-21267.

Lippi G. and Guidi G. (2000). Laboratory screening for erythropoietin abuse in sport: an emerging challenge. Clin Chem Lab Med 38:13-19.

Liu Y., Cox S.R., Morita T., and Kourembanas S. (1995). Hypoxia regulates vascular endothelial growth factor gene expression in endothelial cells. Identification of a 5' enhancer. Circ. Res. 77:638-643.

Magnani M., Corsi D., Bianchi M., Paiardini M., Galluzzi L., Parisi A., and Pigozzi F. (1999). Monitoring erythropoietin abuse in atheletes. Br. J. Haematol. 106:260-261.

Manitius J., Szolkiewicz M., Mysliwska J., Zorena K., Mysliwski A., Jakubovski Z., Lysiak-Szydlovska W., and Rutkovski B. (1995). Influence of nonhematological doses of erythropoietin on lipid-carbohydrate metabolism and life quality in hemodialysis patients. Nephron 69:363-364.

Marber M.S., Walker J.M., Latchman D.S., and Yellon D.M. (1994). Myocardial protection after whole body heat stress in the rabbit is dependent on metabolic substrate and is related to the amount of the inducible 70-kD heat stress protein. J. Clin. Invest. 93:1087-1094.

Marti H.H., Wenger R.H., Rivas L.A., Strumann U., Digicaylioglu M., Henn V., Yonekawa Y., Bauer C., and Gassmann M. (1996). Erythropoietin gene expression in human, monkey and murine brain. Eur. J. Neurosci. 8:666-676

Marti H.H., Bernaudin M., Petit E., and Bauer C. (2000). Neuroprotection and angiogenesis: dual role of erythropoietin in brain ischemia. News Physiol. Sci. 15:225-229.

Melillo G., Musso T., Sica A., Taylor L.S., Cox G.W., and Varesio L. (1995). A hypoxia responsive element mediates a novel pathway of activation of the inducible nitric oxide synthase promoter. J. Exp. Med. 182:16831693.

Michiels C., Arnould T., and Remacle J. (2000). Endothelial cell responses to hypoxia: initiation of a cascade of cellular interactions. Biochim. Biophys. Acta 1497:1-10.

Milledge J.S. and Cotes P.M. (1985). Serum erythropoietin in humans at high altitude and its relation to plasma renin. J. Appl. Physiol. 59:360-364.

Moore, L.G., S. Zamudio, L. Curran-Everett, A. Torroni,
L.B. Jorde, R.V. Shohet and T.T. Drolkar (1994). Genetic adaptation to high altitude. In: . M.Dekker, Inc., New York, pp. 225-262.

Motterlini R., Foresti R., Bassi R., Calabrese V., Clark J.E., and Green C.J. (2000). Endothelial heme oxygenase-1 induction by hypoxia. J. Biol. Chem. 275:13613-13620. Neufeld G., Cohen T., Gengrinovitch S., and Poltorak Z. (1999). Vascular endothelial growth factor (VEGF) and its receptors. FASEB J. 13:9-22.

Noe G., Riedel W., Kubanek B., and Rich I.N. (1992). A sensitive sandwich ELISA for measuring erythropoietin in human serum. Br. J. Haematol. 80:285-292.

Noe G., Waltraut R., Kubanek B., and Rich I.N. (1999). An ELISA specific for murine erythropoietin. Br. J. Haematol. 104:838-840.

Ratcliffe P.J., Ebert B.L., Firth J.D., Gleadle J.M., Maxwell P.H., Nagao M., O'Rourke J.F., Pugh C.W., and Wood S.M. (1997). Oxygen regulated gene expression: erythropoietin as a model system. Kidney Int. 51:514-526.

Rodriguez F.A., Ventura J.L., Casas M., Casas H., Pages T., Rama R., Ricart A., Palacios L., and Viscor G. (2000). Erythropoietin acute reaction and hematological adaptations to short intermittent hypobaric hypoxia. Eur. J. Appl. Physiol. 82:170-177.

Ruschitzka F.T., Wenger R.H., Stallmach T., Quasching T., de Wit C., Wagner K., Labugger R., Kelm M., Noll G., Rulicke T., Shaw S., Lindberg R.L.P., Rodenwald B., Lutz H., Bauer C., Luscher T.F., and Gassmann M. (2000). Nitric oxide prevents cardiovascular disease and determines survival in polyglobulic mice overexpressing erythropoietin. Proc. Natl. Acad. Sci. USA 97: 11609-11613.

Sakanaka M., Wen T.C., Matsuda S., Masuda S., Morishita E., Nagao M., and Sasaki R. (2000). In vivo evidence that erythropoietin protects neurons from ischemic damage. Proc. Natl. Acad. Sci. USA 95:4635-4640.

Samaja M., Brenna L., Allibardi S., and Cerretelli P. (1993). Human red cell aging at $5050 \mathrm{~m}$ altitude: a role during adaptation to hypoxia. J. Appl. Physiol. 75:1696-1701. Schmidt W., Spielvogel H., Eckardt K.U., Quintela A., and Penaloza R. (1993). Effects of chronic hypoxia and exercise on plasma erythropoietin in high/altitude residents. J. Appl. Physiol. 74:1874-1878.

Semenza G.L., Jiang B.H., Leung S.W., Passantino R., Concordet J.P., Maire P., and Giallongo A. (1996a). Hypoxia response elements in the aldolase $\mathrm{A}$, enolase 1 , and lactate dehydrogenase A gene promoters contain essential binding sites for hypoxia-inducible factor 1. J. Biol. Chem. 271:32529-32537.

Semenza G.L., Rue E.A., Iyer N.V., Pang M.G., and Kearns W.G. (1996b). Assignment of the hypoxia-inducible factor 1-_ gene to a region of conserved synteny on mouse chromosome 12 and human chromosome 14q. Genomics 34:437-439.

Semenza G.L. (1998). Hypoxia-inducible factor 1 and the molecular physiology of oxygen homeostasis. J. Labor. Clin. Med. 131:207-214.

Semenza G.L. (2000). Surviving ischemia: adaptive responses mediated by hypoxia-inducible factor 1 . J. Clin. Invest. 106:809-812. 
Severinghaus J.W. (1995). Hypothetical role of angiogenesis, osmotic swelling, and ischemia in high altitude cerebral edema. J. Appl. Physiol. 79:375-379.

Silva M., Grillot D., Benito A., Richard C., Nunez G., and Fernandez-Luna J.L. (1996). Erythropoietin can promote erythroid progenitor survival by repressing apoptosis through bcl-xl and bcl-2. Blood 88:1576-1582.

Sutter C.H., Laughner E., and Semenza G.L. (2000). Hypoxia-inducible factor 1alpha protein expression is controlled by oxygen-regulated ubiquination that is disrupted by deletions and missense mutations. Proc. Natl. Acad. Sci. USA 97:4748-4753.

Tan C.C., Eckardt K.U., Firth J.D., and Ratcliffe P.J. (1992). Feedback modulation of renal and hepatic erythropoietin mRNA in response to graded anemia and hypoxia. Am. J. Physiol. 263:F474-F481.

Tyndall M.R., Teitel D.F., Lutin W.A., Clemons G.K., and Dallman P.R. (1987). Serum erythropoietin levels in patients with congenital heart disease. J. Pediatr. 110:538544.

Voelkel N.F. and Tuder R.M. (2000). Hypoxia-induced pulmonary vascular remodeling: a model for what human disease? J. Clin. Invest. 106:733-738.

Wang G.L., Jiang B.H., Rueand E.A., and Semenza G.L. (1995). Hypoxia indubible factor 1 is a basic helix-loophelix PAS heterodimer regulated by cellular $\mathrm{O} 2$ tension. Proc. Natl. Acad. Sci. USA 92:5510-5514.

Wang X.Q. and Vaziri N.D. (1999). Erythropoietin depresses nitric oxide synthase expression by human endothelial cells. Hypertension 33:894-899.

Weil J., Jamison G., Brown D., Grover R., Balchum O., and Murray J. (1968). The red cell mass-arterial oxygen relationship in normal man. J. Clin. Invest. 47:1627-1639.

Winslow, R.M. and C.C. Monge (1987). Hypoxia, polycythemia, and chronic mountain sickness. Baltimore and London, Johns Hopkins University Press.
Winslow R.M., Chapman K.H., Gibson C.C., Samaja M., Monge C.C., Goldwasser E., Sherpa M., and Blume F.D. (1989). Different hematologic responses to hypoxia in Sherpas and Quechua Indians. J. Appl. Physiol. 66:1561-1569.

Wood S.M., Gleadle J.M., Pugh C.W., Hankinson O., and Ratcliffe P.J. (1996). The role of the aryl hydrocarbon receptor nuclear translocation (ARNT) in hypoxic induction of gene expression. Studies in ARNT-deficient cells. J. Biol. Chem. 271:15117-15123.

Yasuda Y., Masuda S., Chikuma M., Inoue K., Nagao M., and Sasaki R. (1998). Estrogen-dependent production of erythropoietin in uterus and its implication in uterine angiogenesis. J. Biol. Chem. 273:25381-25387.

Yun J.K., McCormick T.S., Judware R., and Lapetina E.G. (1997). Cellular adaptive responses to low oxygen tension: apoptosis and resistance. Neurochem. Res. 22:517-521.

Address reprint requests to: Michele Samaja

Università di Milano

Ospedale San Paolo

Dipartimento di Medicina, Chirurgia e Odontoiatria

via di Rudini 8, I-20142 Milano-Italy

E-mail: Michele.Samaja@unimi.it

Received December 6, 2000; accepted in final form, January 25, 2001 
Errata corrige published in High Alt Med Biol 2002 Spring;3(1):95.

Page 158 (HYPOXIA-INDUCIBLE FACTOR-1]), first para

The structure of HIF-1 1 is now well characterized (Semenza, 1998) and the localization of its gene on human chromosome 14 is established (Semenza et al., 1996b). Technically, HIF-1 1 is a member of the helix-loop-helix PAS family, which belongs to the factors that regulate DNA transcription into mRNA by binding to DNA in the correspondence of specific sequences, or motifs, that are situated upstream affect the expression of many hypoxiainduced genes, which may be situated upstream or downstream (Wang et al., 1995). When the complex HIF-1], HIF-1], and other proteins HIF-1日 recognizes one of these sequences on the DNA strand, it binds to DNA, thereby inhibiting further inducing transcription of that DNA section. When HIF-1 $\mathrm{Q}$ is destabilized, this function is blunted and DNA transcription may proceed is no more induced. Structurally, HIF-1 is a dimer composed of a $\square$ subunit, which is relatively stable and acts as a constitutive factor (Wood et al., 1996), and the $\square$ subunit, which is degraded rapidly and is therefore the limiting factor in the reaction chain (Huang et al., 1998). During hypoxia, the $\square$ subunit becomes stabilized, leading to stabilization of the dimer, its binding to DNA, and inhibition induction of DNA translation into mRNA. 